\title{
Impact of Double Taxation Treaties on Inward FDI in Latin American and Caribbean Developing Countries
}

\author{
Mumtaz Hussain Shah ${ }^{1}$, Saba Qayyum ${ }^{2}$
}

\begin{abstract}
This study strives to assess the impact of double taxation treaties on FDI inflows in 15 Latin American and Caribbean developing countries from 1983 to 2013. There are two objectives of double taxation treaties. The first one is to eliminate the global double taxation, and the second is to barricade the international tax dodging. If we look at the first objective of double taxation treaties (DTTs), it encourages foreign direct investment (FDI) but keeping in view the second objective, it discourages FDI. Both effects can possibly cancel the effect of each other, leaving DTT as an insignificant factor. Previous literature has shown positive, negative and no effect of DTTs on FDI inflows. Therefore, empirically it is an open question that needs further exploration. This study by utilising other conventional FDI determinants such as market size, development level, trade openness and human capital, has empirically shown that DTTs have no effect on the FDI inflows. These countries instead of DTTs seem to be more dependent on some other FDI location pull factors, for example bigger host market, development level, trade openness, the exploitation of their natural resources, improvement of services and manufacturing sector etc. for drawing in foreign direct investment.
\end{abstract}

Keywords: foreign direct investment, double taxation treaties, developing countries, panel data.

\section{Introduction}

Foreign direct investment (FDI) is generally defined as an investment by a firm in another country by acquiring a firm or by increasing existing business operations in that country. International Monetary Fund defines FDI as a minimum 10\% investment with management control. Recently, Latin American and Caribbean (LAC) developing countries have become two of the most sought after FDI destinations. Realising this trend, it seems natural to explore the possible effects of different determinants of FDI in LAC region. The sample of this study is $15 \mathrm{LAC}$ developing counties. The focus of research is on possible effects of different variables such as market size, development level, trade openness, human capital and most importantly double taxation treaties (DTTs) signed by the FDI host on inward FDI. DTT is the key variable of research.

1 Assistant Professor, Institute of Management Studies, University of Peshawar.

2 Postgraduate Scholar, Institute of Management Studies, University of Peshawar. 
Thorough investigation of FDI flows shows an asymmetric trend between different countries and regions of the world (Chalamish, 2011). FDI usually flow from the developed to the developing countries. These countries have different legal, political, and social systems (Shah, 2012a). These disparities give rise to a diverse set of basic questions. The two most important issues raised are the security of an investor's investment in insecure states, and double taxation. In order to minimize these problems, developed and developing countries started signing bilateral agreements such as bilateral investment treaties (BITs) and DTTs (Shah, 2011c).

The main function of a DTT is to eliminate double taxation and bring tax evasion to an end. These treaties are particularly created for reducing the barriers to FDI between two or more economies (Shah, 2010). If seen theoretically, these treaties should increase international investment flows by providing security to foreign investor in the host country and reducing taxation costs. However, the costs of concluding and negotiating these treaties have become an important factor especially for the developing host government with financial constraints. Consequently, it has become a question mark in the field of international finance that whether the benefits of DTTs exceed their costs? It is an unresolved modern world riddle that whether these treaties increase FDI, decrease FDI or both the effects cancel the influence of each other, making DTTs inconsequential?

Therefore, as the importance of FDI increases, the importance of tax treaties also increases (Shah, 2011b). According to Ohno (2010), tax treaty is the cooperation between two states. The increasing trend of FDI increased the importance of international double taxation issues in two ways. First, double taxation occurs because taxation is the sovereign right of every state. It, however, creates problems as well. If the revenues of a multi-national firm are taxed initially by the host country followed by home country, then this is the occurrence of double taxation on the same income. This double taxation decreases the advantages or proceeds from FDI. Therefore, nations around the world concluded DTT's to tackle this problem. Second, it is about the avoidance of international tax. Since it is difficult to know the exact profits of a foreign subsidiary as compared to revenues of the parent company in the home country, hence the governments of source and host country cooperate with each other and conclude tax treaties in order to prevent tax avoidance. If the governments do not take any action concerning this problem then the investors will evade tax. Therefore, there are two objectives of double taxation treaties. The first one is to do away with international double taxation and the second is to prevent international tax evasion. Consequently, there are two possible ways by which a tax treaty affects FDI. In the light of the first objective of DTTs, it promotes FDI because it helps in reducing the negative effects of double taxation. While looking at the second objective, 
it discourages FDI because it prevents tax evasion. These two opposing influences of double taxation treaties on FDI make it difficult to decide whether these treaties actually affect foreign direct investment? If they affect, then which of the two effects overwhelms the other? This is the query this study intends to answer empirically.

Existing research is inconclusive about the effects of DTTs on FDI inflows. This is manifested by the literature review as well. Therefore it is necessary to find the answer to this research question by taking data for a new sample of countries, e.g. Latin American and Caribbean, and a different time period, i.e. 1983 to 2013. Such treaties also generally impose a non-trivial check on their authority to tax commercial profits of foreign firms. If the anticipated increase in FDI fails to materialise, then the resources used in concluding DTTs are wasted without any possibility of salvaging the incurred costs.

This study will add to the literature of international finance and investment. It is expected to be of value for contemporary researchers, students of FDI, and all developing countries because it re-addresses a very important question. For academic researchers and FDI students it will update and revise the existing FDI - DTT literature. This study will add to the knowledge of strategy makers, international investors, host countries and other stakeholders of multi-national business. It will help developing countries in adopting new procedures to attract FDI. As the importance of FDI is increasing, therefore the policy makers should be aware of the benefits and limitations of double taxation treaties in this context. Only then they can not only set realistic prospects but also achieve them by wisely formulating international trade and investment strategies.

The current sample comprises of only 15 LAC countries. Other developing nations can also benefit from the results of this study. However, they need to keep in mind whether the socio-economic conditions in those countries are similar to LAC nations or not. It is because each state should formulate business and investment strategies in accordance with its own needs, strengths, and core competencies.

\section{Literature Review}

The literature review comprises of three parts. The first section summarises the significance of FDI for developing countries. The second one discusses the conventional FDI determinants, while the third section covers the DTT - FDI relationship.

\subsection{FDI and Developing Countries}

Christiansen (2002) discussed the importance of FDI in an overview on "foreign direct investment for development". It is argued that economic development, modern- 
ization, employment and income growth in transition economies, developing countries and emerging economies, are all based on FDI. It works as a catalytic foundation for all these developments. Realising the importance of FDI governments around the globe, focus on improving their business policies in order to get their due share of overseas investment (Shah, 2011e). Empirical work substantiates that FDI advances technology spill overs, improves human capital, assist enterprise development and engenders competitive atmosphere in the host economy. All these factors help in reducing poverty and leads to economic growth. Social environment may also improve because foreign investors prefer socio-economic harmony. Agiomirgianakis, Asteriou and Papathoma (2004) stated that open door policy for FDI is globally adopted by countries because it boosts employment and investment opportunities, and in general, fosters economic development of the host nation. The authors gave the example of Barrell and Pain (1997) and stated that due to FDI inflows, Great Britain enjoys 30\% growth in manufacturing productivity. Furthermore, according to Wang (1990), FDI has both direct and indirect effects on a country. It directly asserts a positive influence on the production of a country through knowledge transfer and indirectly it elevates workforce quality in the host state (Shah, 2009).

According to UNCTAD (2009), only a few bigger developing economies are the primary recipients of the $27.3 \%$ of total FDI flowing into developing world, while the rest are still struggling to catch the attention of the multi-nationals (Shah, 2013b). Mottaleb and Kalirajan (2010) state that FDI is the basis for the economic development of a country and developing countries are the main receivers of FDI. Testing their hypotheses on 31 low income earner countries and 37 middle income earner nations from Africa, Asia and Latin America for the time period of 2005-2007, it was found that Asian countries in general draw more FDI as compared to Latin American and low income African nations. The econometric results prove that countries where GDP, growth rate of GDP, the volume of international trade and business environment are better, attracts more FDI.

\subsection{FDI Determinants - Control Variables}

Keeping in view the advantages of FDI, developing countries are aggressively competing with one another for inward FDI by focusing mostly on their location specific attributes (Shah, 2013a). According to Nunnenkamp (2002), the importance of various types of FDIs is different from one another, and so are their respective determinants. They can be divided into three groups of location specific determinants. First, based on the policy structure for FDI, second, the economic determinants, and third, the measures for investor facilitation. It was further proposed that there are many external factors which influence FDI flows. Consequently, while developing strategies, the 
policy makers should not be surprised if the determinants that positively affect FDI elsewhere are not making positive effects locally.

It is stated in UNCTAD (1996) that the significance of FDI determinants has changed because of globalization. Earlier, market size was a vital determinant but in subsequent years, other factors gained importance like the cost difference in different locations, quality of infrastructure (Shah, 2014b), human capital and business environment (Shah, 2012c) in the host country. Similarly, Loree and Guisinger (1995) argued that GDP per capita was a critical variable for FDI but it lost its importance with the passage of time. The authors argued that the shift from local market oriented FDI to world market seeking FDI is the main reason for these varying results. Therefore, exploring the impact of different determinants of FDI continues to be an important topic for empirical research (Shah and Faiz, 2015). Nunes and Oscategui (2006) explored the variables affecting FDI flows to 15 Latin American emerging markets from 1991 to 1998. Their dependent variable was FDI inflows and independent variables were openness, market size, infrastructure, macroeconomic stability, wages, human capital, and natural resources. Results showed positive relation of openness of the economy, infrastructure and market size with FDI whereas inflation, and wages or labour cost had negative relation with FDI. According to their results, privatization does not have any impact on FDI.

According to Foreign Investment Advisory Service (2002), FDI flows to developing countries are positively affected by GDP per capita. FDI inflow is attracted by development level and growth rate of a country (Shah, 2012b). But Akin (2009) argues that population and GDP are more important factors as compared to GDP per capita. According to him, higher purchasing power of people attracts more FDI. Goldar and Banga (2004) studied the effect of trade liberalization on FDI in Indian industries. According to them, among two similar partner countries with intra-industry trade, the country with lower manufacturing cost and better environment for FDI will attract additional investment (Shah, 2011a).

Noorbakhsh, Paloni \& Youssef (2001) studied the impact of human capital on FDI in 36 countries from Asia, Latin America, and Africa from 1980 to 1994. They found that with passage of time the importance of human capital is increasing. Velde (2001) also discussed different policies which improve inward FDI. He suggested that although it is very expensive but education policy is the best way to develop human capital of a country. The author mentioned some of the problems that arise by focusing on low skilled FDI, e.g. facing complexities in the long run development of human capital. According to Blomström, Kokko \& Mucchielli (2003), FDI inflow is very important for technological development and economic growth of an economy. If a country has skilled and educated labour force, it benefits more from advance technol- 
ogy. They concluded that a country attracts more FDI by enhancing its infrastructure, human capital, and economic growth. Khan (2007) stated that developing countries can use human capital as a competitive edge. By giving the example of Singapore, he argued that it is deficient in natural resources but attracts FDI because of its highly competitive low cost human capital. Shah (2014a) also found human capital to be positively affecting inward FDI.

Of the numerous FDI determinants, this study focuses on some of the key conventional locational FDI pull factors such as market size, development level, human capital, trade openness, and double taxation treaties.

\subsection{Double Taxation Treaties}

Double taxation treaties (DTTs) is the main variable of interest of this study. Academics have shown mixed effects of DTTs on FDI. Some has shown positive, some negative, and others have concluded that there is no association between DTTs and FDI. Blonigen and Davies (2004) and Egger, Larch, Pfaffermayr and Winner (2006) state that each type of DTT has different effect because all the DTTs are not equally enforced; therefore, their impact cannot be the same. Büthe and Milner (2009) argued that BITs and DTTs play a vital role in attracting foreign investment by making the country's business and investment environment better. Countries signed BITs and DTTs even when there was no proof of their influence on FDI flows. However, evidence of their possible positive association increased the number of such agreements. More specifically, the developing countries gave more attention to treaties in order to stay competitive in their quest for FDI (Shah, 2011d).

Neumayer (2007) for the very first time provided statistical evidence that signing DTTs with US or other highly developed countries can boost FDI inflows to developing countries. He applied fixed effects panel estimation technique on annual data for 1970 to 2001. It is argued that DTTs are effective for middle income but not for low income developing countries. Barthel, Busse, and Neumayer (2010) stated that policy makers, in order to attract more FDI, are busy in making policies for increasing technological advancement, providing capital advantages, and improving competition in the host states. The study considered DTTs to be one of the most essential policy tools. They took 30 source and 105 host countries as a sample. Among the source countries 10 were developing; and among the host nations 84 were developing economies. Their results showed that DTTs increase FDI inflows in the host countries.

Murthy and Bhasin (2013) attempted to find the effect of DTTs on FDI inflows in India. The control variables taken by them were FDI, openness, GDPPC and GDP. Using fixed effects panel model, it was shown that DTTs have very slight but positive 
impact on FDI inflows to India. Blonigen and Davies (2004) studied the relationship of US' inward and outward FDI and DTTs from 1966 to 1992. According to them, FDI is not affected by new treaties but as the treaties get old, they become more significant. Their results showed that DTTs have positive relation with FDI and these treaties increase FDI activity. Similarly, Blonigen and Davies (2005) analysing the effect of old and new DTTs on FDI in OECD countries from 1982 to 1992 found that, new treaties had negative and insignificant effects while the old treaties had positive and significant effects on FDI activity. The combined effect of both old and new treaties was significant and positive. Therefore, the authors argued that for a short period of time, a treaty has negative impact and will reduce FDI activity; whereas it has a positive impact in the long run. Egger et al. (2006) also concluded that there is a significant negative effect of DTTs on outward FDI from OECD countries to a developing host.

Ohno (2010) evaluating the effect of DTTs on Japanese FDI in 13 Asian countries from 1981 to 2003 showed that the new treaties have significant positive impact on FDI. He argued that as time passes and the treaties become old or are revised, they lose their significance. Millimet and Kumas (2009) using panel data for US inbound and outbound FDI over the years 1980 to 1990, stated that new treaties have positive impact if the level of FDI in a country is low. However, the new treaty will assert a negative impact if FDI activity is already high in a country.

There are researchers who have shown that DTTs have no impact on FDI. For example, Coupé, Orlova and Skiba (2008) studying the impact of BITs and DTTs on FDI found that BITs have a positive impact on FDI while DTTs have an insignificant impact. Countries which have signed BITs with OECD countries will receive more FDIs while signing DTTs exerts no effect. Baker (2014) argued that less developed countries are the chief importers; therefore for import substitution they try to make the business environment better for investors from abroad. They sign double taxation treaties in order to attract foreign investors. Though they have to bear costs by reducing the tax rate after negotiating the treaty, yet it is also true that in this way they can become hubs of inward FDIs. The author showed that DTTs have insignificant impact on FDIs. There were cases where no difference has been found between the taxes after signing the treaty and non-treaty taxes. In such situations there is no need to waste time and resources on negotiating a treaty. The author recommends that the strategy makers of least developed countries (LDC) should first investigate the benefits and costs of signing a new treaty. Only after examining the potential advantages they should come to the decision whether signing such treaties is better for a particular country or not. They should be very confident prior to concluding a treaty, for only then they can get the expected results.

A lot of work has already been done on the objective of this study. We have seen 
different effects of DTTs on FDI from the literature. This is because all the researchers have taken dissimilar samples, diverse control variables and have used different estimation techniques in their research. This study is carried out for a distinct sample of LAC countries using different control variables for a different time period from 1983-2013. No one before has carried out research for a sample similar to this study in all respects ${ }^{3}$. Looking at the literature and at the varying impacts of DTTs on FDI in different situations, it is necessary to carry out a nouvelle research to discover the possible effect of DTTs on FDI in Latin American and Caribbean countries.

These countries are rich in natural resources, and have a developing manufacturing sector with smooth and business friendly economic policies (ECLAC, 2013). On the basis of knowledge gained from the literature and after knowing the facts about the sample countries, it can be expected that there may be a positive, negative, or insignificant impact of DTTs on FDI. These countries are already taking advantage of other prospective FDI determinants. Nonetheless, we cannot say anything from ourselves. Our expectations and our hypothesis based on theory and current literature might not be always true. However, an empirical investigation will provide better results.

\section{Methodology}

\subsection{Sample}

The sample of this study consists of 15 Latin American and Caribbean developing countries, including Argentina, Barbados, Brazil, Chile, Colombia, Costa Rica, Ecuador, El Salvador, Honduras, Jamaica, Mexico, Panama, Paraguay, Peru and Venezuela. Data for 31 years, that is, from 1983 to 2013 is utilised.

\subsection{Data Sources}

Only secondary data is used in this research. The primary focus is to analyse the possible effects of DTTs signed by the FDI host on inward FDI. The influence of other essential FDI location pull factors, for example: host market size, its development level; trade openness and human capital are also considered along with the key variable of research. Sources of all the variables are given below in Table 1:

3 . For example Nunes and Oscatengi (2006) though, investigated the conventional FDI locational pull factors effecting inward FDI in 15 LAC countries from 1991-1998, their work differs from the current in the following aspects: one they have not analysed DTTs, two the sample countries are different, three the time period is different and four even the other control variables used and their proxies are also not exactly the same. 
Table 1: Variable Sources

\begin{tabular}{|c|c|c|c|}
\hline Dependent Variable & $\begin{array}{l}\text { Independent Vari- } \\
\text { ables }\end{array}$ & Proxies used & Sources \\
\hline FDI & & FDI inflows & $\begin{array}{c}\text { WDI, World Bank } \\
\text { Website }\end{array}$ \\
\hline & \multirow[t]{2}{*}{ Market Size } & GDP & $\begin{array}{c}\text { WDI, World Bank } \\
\text { Website }\end{array}$ \\
\hline & & Population & $\begin{array}{l}\text { WDI, World Bank } \\
\text { Website }\end{array}$ \\
\hline & Development Level & GDPPC & $\begin{array}{c}\text { WDI, World Bank } \\
\text { Website }\end{array}$ \\
\hline & \multirow[t]{2}{*}{ Human Capital } & Primary Education & $\begin{array}{c}\text { WDI, World Bank } \\
\text { Website }\end{array}$ \\
\hline & & Secondary Education & $\begin{array}{c}\text { WDI, World Bank } \\
\text { Website }\end{array}$ \\
\hline & Trade Openness & Trade as $\%$ of GDP & $\begin{array}{c}\text { WDI, World Bank } \\
\text { Website }\end{array}$ \\
\hline & \multirow{2}{*}{$\begin{array}{c}\text { Double Taxation } \\
\text { Treaties }\end{array}$} & Current Year DTTs & \multirow[t]{2}{*}{ UNCTAD website } \\
\hline & & Cumulative Year DTTs & \\
\hline
\end{tabular}

\subsection{Descriptive Statistics}

Its aim is to summarize the sample and the observations taken for the study. These summaries give the basis for initial description of the data. At times they may be sufficient for answering the main question of the study. The summary statistics are given as Table 2 .

\subsection{Correlation Matrix}

High correlations of $90 \%$ or above between independent variables indicate the possible existence of multi-collinearity (Shah and Samdani, 2015). The correlation between all the independent variables is given as Table 3. As, evident from the correlation matrix some of the variables exhibit a very high correlation between them. Therefore GDP, population and primary education are not included in a single regression model in the results and analysis section.

\subsection{Heteroscedasticity}

To check for the presence of heteroscedasticity in the dependent and all the 
Table 2: Descriptive Statistics

\begin{tabular}{|c|c|c|c|c|c|c|c|}
\hline Variables & Proxy Used & Obs & Min & Max & Mean & Median & Std Dev \\
\hline $\begin{array}{c}\text { Foreign Direct } \\
\text { Investment }\end{array}$ & Ln FDI & 465 & -21.84 & 24.70 & 18.30 & 19.95 & 7.83 \\
\hline Market Size & Ln GDP & 465 & 20.57 & 28.39 & 24.02 & 23.73 & 1.75 \\
\cline { 2 - 8 } & Ln Population & 465 & 12.42 & 19.09 & 16.13 & 16.23 & 1.57 \\
\hline $\begin{array}{c}\text { Development } \\
\text { Level }\end{array}$ & Ln GDPPC & 465 & 6.39 & 9.618 & 7.89 & 7.88 & 0.72 \\
\hline \begin{tabular}{c} 
Human Capital \\
\cline { 2 - 8 }
\end{tabular} & Ln Pri Edu & 465 & 10.01 & 17.39 & 14.18 & 14.31 & 1.61 \\
\hline $\begin{array}{c}\text { Lrade Open- Edu } \\
\text { ness }\end{array}$ & 465 & 6.08 & 17.10 & 13.35 & 13.57 & 2.12 \\
\hline $\begin{array}{c}\text { Ln Trade } \\
\text { Double Taxa- }\end{array}$ & 465 & 2.53 & 5.29 & 4.05 & 4.07 & 0.60 \\
\cline { 2 - 8 } Treaties & $\begin{array}{c}\text { Ln DTTs } \\
\text { Ln Cumulative } \\
\text { DTTs }\end{array}$ & 465 & 0.00 & 3.81 & 1.39 & 1.36 & 1.08 \\
\hline
\end{tabular}

The values are rounded off to two decimal places

Table 3: Correlation Matrix

\begin{tabular}{|c|c|c|c|c|c|c|c|c|c|c|c|}
\hline No & $\begin{array}{l}\text { Variable } \\
\text { Name }\end{array}$ & Proxy used & 1 & 2 & 3 & 4 & 5 & 6 & 7 & 8 & 9 \\
\hline 1 & $\begin{array}{c}\text { Foreign } \\
\text { Direct } \\
\text { Investment }\end{array}$ & Ln FDI & 100 & & & & & & & & \\
\hline 2 & \multirow[t]{2}{*}{ Market Size } & Ln GDP & 37 & 100 & & & & & & & \\
\hline 3 & & Ln Population & 30 & 91 & 100 & & & & & & \\
\hline 4 & $\begin{array}{l}\text { Develop- } \\
\text { ment Level }\end{array}$ & Ln GDPPC & 26 & 44 & 03 & 100 & & & & & \\
\hline 5 & \multirow{2}{*}{$\begin{array}{l}\text { Human } \\
\text { Capital }\end{array}$} & Ln Pri Edu & 27 & 87 & 99 & -05 & 100 & & & & \\
\hline 6 & & Ln Sec Edu & 20 & 61 & 62 & 13 & 62 & 100 & & & \\
\hline 7 & $\begin{array}{c}\text { Trade Open- } \\
\text { ness }\end{array}$ & Ln Trade & -15 & -67 & -76 & 03 & -75 & -40 & 100 & & \\
\hline 8 & \multirow{2}{*}{$\begin{array}{l}\text { Double } \\
\text { Taxation } \\
\text { Treaties }\end{array}$} & $\begin{array}{l}\text { Ln Current } \\
\text { year DTTs }\end{array}$ & 19 & 34 & 23 & 33 & 20 & 14 & -12 & 100 & \\
\hline 9 & & $\begin{array}{l}\text { Ln Cumula- } \\
\text { tive DTTs }\end{array}$ & 23 & 51 & 26 & 67 & 19 & 26 & -11 & 50 & 100 \\
\hline
\end{tabular}

The correlation are reported in percentages to the nearest whole number 
Table 4: Breusch - Pagan / Cook - Weisberg test Results

\begin{tabular}{|c|c|c|c|}
\hline Variable(s) & Chi $^{2}$ & Probability $>$ Chi $^{2}$ & Decision \\
\hline Ln FDI & 90.40 & 0.0000 & Heteroscedastic \\
\hline Ln GDP & 107.98 & 0.0000 & Heteroscedastic \\
Ln GDPPC & & & \\
Ln SecEdu \\
Ln Trade \\
Ln CurrentYearDTT \\
Ln Cumulative- \\
YearDTT
\end{tabular}

explanatory variables Breusch - Pagan / Cook - Weisberg test for heteroscedasticity is performed. The results are provided as Table 4 .

Ho: Constant variance

It shows the presence of heteroscedasticity in the dependent and all the independent variables because in both the cases we are able to reject the null hypothesis of homoscedasticity. Therefore, all the regressions are performed by applying the robust option. All the results reported in the results and analysis section is after controlling for heteroscedasticity (Shah, 2015).

\subsection{Statistical Model}

The statistical equation quantifying the relationship between FDI and the independent variables is given below as equation 1 :

FDI inflows $=f[$ Market Size, Development Level, Human Capital, Trade Openness, Double Taxation Treaties]

Equation 1 is Log-linearized to smooth out the data and reduce the extent of heteroscedasticity in the variables included in the estimations. Based on the literature review and data availability the variables in equation 1 are replaced with possible appropriate proxies and the resultant equation is given as equation 2:

Ln FDI $I_{j t}=\alpha_{0}+\beta_{1} L_{n} G_{j D}+\beta_{2} L_{n} G_{j D P C}+\beta_{3}$ Ln Primary Or Secondary Edu-

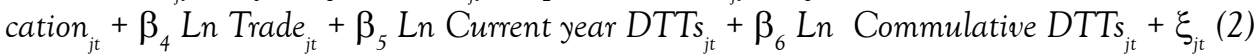

Where,

Ln FDI is the natural logarithm of FDI inflows to countries included in the sample in million US dollars for time period $(\mathrm{t})$. 
Ln GDP is gross domestic product in US dollars. It is used as a proxy for market size.

Ln GDP/PC is gross domestic product per capita. It is a proxy for developmental level.

Ln primary or secondary school education is used as a proxy for human capital.

Ln Trade is used as a proxy for the openness of the host market.

Ln Current year DTTs is the natural log of the number of double taxation treaties signed in the current year.

Ln Cumulative DTTs is the natural log of aggregate double taxation treaties signed till that year.

\subsection{Hausman Specification Test}

Having observations for 15 countries for 31 years for all the variables used in the study, the appropriate way to arrange the data is in a panel form. There are two common methods to analyse panel data: one fixed effect and the second random effects. To choose the suitable method the Hausman (1978) specification test was performed and the results are given as Table 5 .

Ho: Difference in coefficients not systematic or $\mathrm{Chi}^{2}(6)=(\mathrm{b}-\mathrm{B})^{\prime}\left[\left(\mathrm{V}_{-} \mathrm{b}-\mathrm{V} \_\mathrm{B}\right) \wedge\right.$ $(-1)](b-B)$

Table 5: Hausman Specification Test Results

\begin{tabular}{|c|c|c|c|}
\hline Variables & Chi $^{2}$ & Probability $>$ Chi $^{2}$ & Decision \\
\hline Ln GDP & 32.96 & 0.0000 & Fixed Effect Method \\
Ln GDPPC & & & \\
Ln SecEdu & & & \\
Ln Trade & & & \\
Ln CurrentYear DTT & & & \\
Ln CumulativeYear & & & \\
DTT & & & \\
\hline
\end{tabular}

\section{Results and Analysis}

The results presented in Table 6 for the six regressions/models estimated are obtained through fixed effects panel estimation method. In Table 6, model 1 and 2 clearly manifest the importance of market size and development level for overseas investors in Latin American and Caribbean developing economies. The same is true for trade openness as evident from model 4 to 6 . Human capital in model 3 has a 
negative sign contrary to expectations, but thankfully fails to reach conventional significant levels. This may be due to the fact that educational literacy was always good in the selected sample countries. Moreover, GDPPC along with development level and purchasing power is also a yard stick for human capital accretion in the host market. Therefore, the insignificance of the primary and secondary education may have been caused by GDPPC being significant. Hence, GDPPC may be swamping the possible positive effects of human capital.

Table 6: Estimation Results - Panel Fixed Effect Estimation

\begin{tabular}{|c|c|c|c|c|c|c|c|c|}
\hline No & $\begin{array}{c}\text { Variable } \\
\text { Name }\end{array}$ & $\begin{array}{l}\text { Proxy } \\
\text { Used }\end{array}$ & 1 & 2 & 3 & 4 & 5 & 6 \\
\hline 1 & $\begin{array}{l}\text { Market } \\
\text { Size }\end{array}$ & Ln GDP & $\begin{array}{c}1.879^{* * *} \\
(0.384)\end{array}$ & $\begin{array}{c}1.475^{* * *} \\
(0.214)\end{array}$ & $\begin{array}{c}1.557^{* * *} \\
(0.266)\end{array}$ & $\begin{array}{c}2.172^{* * *} \\
(0.318)\end{array}$ & $\begin{array}{c}2.083^{* * *} \\
(0.330)\end{array}$ & $\begin{array}{c}2.142^{* * *} \\
(0.278)\end{array}$ \\
\hline 2 & $\begin{array}{c}\text { Devel- } \\
\text { opment } \\
\text { Level }\end{array}$ & $\begin{array}{c}\text { Ln GDP- } \\
\text { PC }\end{array}$ & & $\begin{array}{l}1.674^{* * *} \\
(0.879)\end{array}$ & $\begin{array}{c}1.671^{*} \\
(0.868)\end{array}$ & $\begin{array}{c}0.866 \\
(1.015)\end{array}$ & $\begin{array}{c}0.858 \\
(1.084)\end{array}$ & $\begin{array}{c}0.982 \\
(1.062)\end{array}$ \\
\hline 3 & $\begin{array}{l}\text { Human } \\
\text { Capital }\end{array}$ & $\begin{array}{l}\text { Ln Sec- } \\
\text { ondary } \\
\text { Educa- } \\
\text { tion }\end{array}$ & & & $\begin{array}{c}0.982 \\
(1.062)\end{array}$ & $\begin{array}{l}-0.135 \\
(0.089)\end{array}$ & $\begin{array}{l}-0.122 \\
(0.092)\end{array}$ & $\begin{array}{c}-0.112 \\
(0.099)\end{array}$ \\
\hline 4 & $\begin{array}{l}\text { Open- } \\
\text { ness }\end{array}$ & $\begin{array}{l}\text { Ln } \\
\text { Trade }\end{array}$ & & & & $\begin{array}{l}2.086^{* *} \\
(0.850)\end{array}$ & $\begin{array}{l}1.990^{* *} \\
(0.887)\end{array}$ & $\begin{array}{l}2.103^{* *} \\
(0.876)\end{array}$ \\
\hline 5 & $\begin{array}{c}\text { Double } \\
\text { Taxation } \\
\text { Treaties }\end{array}$ & $\begin{array}{l}\text { Ln Cur- } \\
\text { rent Year } \\
\text { DTTs }\end{array}$ & & & & & $\begin{array}{c}0.940 \\
(0.780)\end{array}$ & $\begin{array}{c}1.083 \\
(0.816)\end{array}$ \\
\hline 6 & & $\begin{array}{c}\text { Ln Cu- } \\
\text { mulative } \\
\text { DTTs }\end{array}$ & & & & & & $\begin{array}{l}-0.257 \\
(0.535)\end{array}$ \\
\hline \multicolumn{3}{|c|}{ Number of Observations } & 465 & 465 & 465 & 465 & 465 & 465 \\
\hline \multicolumn{3}{|c|}{ R-Square } & $13.81 \%$ & $14.83 \%$ & $14.85 \%$ & $15.70 \%$ & $15.80 \%$ & $15.92 \%$ \\
\hline
\end{tabular}

* represents significance at $10 \%,{ }^{* *}$ at $5 \%$ and ${ }^{* * *}$ represents significance at $1 \%$ level. Standard errors robust to heteroscedasticity are reported in parenthesis below the coefficients

Current year double taxation treaties (model 5) as well as cumulative double taxation treaties (model 6) are both insignificant. This, when read together with the significant coefficient for market size and development level, shows that the nature of FDI in the region is of horizontal market seeking nature. In horizontal FDI the primary importance is that of the host market size and the ability of its inhabitants to buy the end product (Shah, 2012d). However, due to DTTs importance from literature review it cannot be altogether excluded from a coherent strategy formulated 
by a developing country to attract more FDIs. Better insights into the causes of its insignificance can be obtained with the future availability of disaggregated sectoral FDI statistics.

\section{Conclusion}

The empirical results of this study show that tax treaties do not have any effect on foreign direct investment inflows to Latin American and Caribbean developing countries. The reason can be that developing countries keep their tax rate very low because they want to attract foreign investors. These countries invite foreign investors and fiercely compete with other nations to become the most attractive location for multi-nationals (Shah, 2011f). Another dynamic of the insignificance of DTTs on FDI inflows in these states can be the fact that foreign investors seek their abundant natural resources. For example according to ECLAC, (2013) in 2012, 51\% of the investment went into mining alone, $12 \%$ in manufacturing and $37 \%$ into services sector. The results also clearly demonstrate that some factors other than DTTs such as market size, development level, and openness affect FDI inflows in Latin American and Caribbean countries.

Nonetheless, these arguments do not imply that DTTs do not have any role in increasing FDI inflows; rather it depends more on the region and time period chosen for the research. Though Latin American and Caribbean countries do not depend on DTTs for attracting FDI inflows, yet for other regions of the world these might be significant factors. The available resources and business conditions of every country are different. Therefore, each country should focus on its own competencies and advantages in order to attract FDI.

It is also possible that today DTT may not be a significant factor for a region but tomorrow it might become important for the same region. Time is one of the vital elements for carrying out any research. Therefore, it is recommended that this process should not be stopped here. Further researches should be carried out with comprehensive micro-sectoral data in future to find out which factors are significant for attracting FDI at a particular time, for a specific sector, in a certain region.

\section{References}

Agiomirgianakis, A.G.M., Asteriou, D., \& Papathoma, K. (2004). The determinants of foreign direct investment. Aspects of Globalisation: Macroeconomic and Capital Market Linkages in the Integrated World Economy.

Akin, M.S. (2009). How is the market size relevant as a determinant of FDI in developing countries? A research on population and the cohort size. In: International Symposium on Sustainable Devel- 
opment, June 9-10, 2009. Sarajevo, Bosnia and Herzegovina, 425-429.

Baker, P.L. (2014). An analysis of double taxation treaties and their effect on foreign direct investment. International Journal of the Economics of Business, 21(3), 341-377.

Barrell, R., \& Pain, N. (1997). Foreign direct investment, technological change, and economic growth within Europe. The Economic Journal, 107(445), 1770-1786.

Barthel, F., Busse, M., \& Neumayer, E. (2010). The impact of double taxation treaties on foreign direct investment: evidence from large dyadic panel data. Contemporary Economic Policy, 28(3), 366-377.

Blomström, M., Kokko, A., \& Mucchielli, J.L. (2003). The economics of foreign direct investment incentives (37-60). Springer Berlin Heidelberg.

Blonigen, B.A., \& Davies, R.B. (2004). The effects of bilateral tax treaties on US FDI activity. International Tax and Public Finance, 11(5), 601-622.

Blonigen, B.A., \& Davies, R.B. (2005). Do bilateral tax treaties promote foreign direct investment? Handbook of international trade, 2, 526-546.

Büthe, T., Milner, H.V. (2009). Bilateral investment treaties and foreign direct investment: A political analysis. In: Sauvant K.P., \& Sachs L.E. (Eds.), The effect of treaties on foreign direct investment: Bilateral investment treaties, double taxation treaties, and investment flows. (pp. 171-224). Oxford University Press.

Chalamish, E. (2011). Do treaties matter? On effectiveness and international economic law. Mich. J. Int'l L., 32(2), 325-765.

Coupé, T., Orlova, I., \& Skiba, A. (2008). The effect of tax and investment treaties on bilateral FDI flows to transition countries. 9th Annual Global Development Conference, Brisbane (Vol. 29).

ECLAC. (2013). Foreign investment in Latin America and the Caribbean in 2012. Economic Commission for Latin America and the Caribbean, Santiago: United Nations publication.

Egger, P., Larch, M., Pfaffermayr, M., \& Winner, H. (2006). The impact of endogenous tax treaties on foreign direct investment: Theory and evidence. Canadian Journal of Economics, 39(3), 901-931.

Foreign Investment Advisory Service (2002). Senegal: Leparcours de l'investisseur-Une Reevaluation Unpublished Paper. Washington, D.C.: The World Bank.

Goldar, B., \& Banga, R. (2007). Impact of trade liberalization on foreign direct investment in Indian industries. Perspectives on equitable development: international experience and what can India learn.

Hausman, J.A. (1978). Specification tests in econometrics. Econometrica, 46(6), 1251-1271.

Khan, M.A. (2007). Role of human capital in attracting foreign direct investment: A South Asian perspective. SAARC Journal HRD, 3(1), 5.

Loree, D.W., \& Guisinger, S.E. (1995). Policy and non-policy determinants of US equity foreign direct investment. Journal of International Business Studies, 26(2), 281-299. 
Millimet, D.L., \& Kumas, A. (2009). It's all in the timing: assessing the impact of bilateral tax treaties on US FDI activity.

Mottaleb, K.A., \& Kalirajan, K. (2010). Determinants of foreign direct investment in developing countries a comparative analysis. Margin: The Journal of Applied Economic Research, 4(4), 369-404.

Murthy, K.V., \& Bhasin, N. (2013). The impact of bilateral tax treaties on FDI inflows: The case of India. Mimeo. [http://papers.ssrn.com/sol3/papers.cfm?abstract_id=2234966].

Neumayer, E. (2007). Do double taxation treaties increase foreign direct investment to developing countries? The Journal of Development Studies, 43(8), 1501-1519.

Noorbakhsh, F., Paloni, A., \& Youssef, A. (2001). Human capital and FDI inflows to developing countries: new empirical evidence. World development, 29(9), 1593-1610.

Nunes, L.C., \& Oscategui, J. (2006). Determinants of FDI in Latin America (No. 2006-252). Departamento de Economía-Pontificia Universidad Católica del Perú.

Nunnenkamp, P., \& CUTS Centre for International Trade, Economics \& Environment (Jaipur, India). (2002). Foreign Direct Investment in developing countries: what economists (don't) know and what policymakers should (not) do! CUTS Centre for International Trade, Economics \& Environment.

Christiansen, H. (2002). Foreign direct investment for development-maximising benefits, minimising costs: overview. DAFFE/IME (2002), 5, 15.

Ohno, T. (2010). Empirical analysis of international tax treaties and foreign direct investment. Public Policy Review, 6(2), 287-312.

Shah, M.H., (2009). FDI induced growth in developing countries: does human capital matter? PhD Conference. $5^{\text {th }} \& 11^{\text {th }}$ March, 2009. Economics Department, University of Leicester, Leicester, UK.

Shah, M.H., (2010). Bilateral linkages with OECD and FDI inflows in leading developing countries. The Fifth International Conference on Interdisciplinary Social Sciences. 2-5 August, 2010. University of Cambridge, Cambridge, UK.

Shah, M.H., (2011a). Bilateral linkages with OECD and FDI inflows in leading developing countries. International Journal of Interdisciplinary Social Sciences, 5(7), 255-270.

Shah, M.H. (2011b). Essays on foreign direct investment in developing countries (Doctoral dissertation, University of Leicester).

Shah, M.H., (2011c). The Effect of associations with OECD economies on FDI inflows in leading/emerging developing countries. $4^{\text {th }}$ Italian Doctoral Workshop in Economics and Policy Analysis. 7-8 July, 2011. University of Torino and Collegio Carlo Alberto, Via Real Collegio 30, 10024 Moncalieri, Torino, Italy.

Shah, M.H., (2011d). Networking with OECD economies, enhancing inward FDI in emerging developing countries. $7^{\text {th }}$ UK Social Networks Conference. 7-9 July, 2011. University of Greenwich, Greenwich Campus, 
Old Royal Naval College, London, UK.

Shah, M.H., (2011e). World Trade Organisation and inward foreign direct investment in developing countries: is it TRIMS, TRIPS or Liberalisation? $6^{\text {th }}$ International Conference on Interdisciplinary Social Sciences. 11-13 July, 2011. University of New Orleans, 2045 Lakeshore Drive, CERM 245, New Orleans, LA 70122, USA.

Shah, M.H., (2011f). The significance of infrastructure for inward FDI in developing countries. International Conference on Applied Business \& Economics, ICABE, 2011. 29 th $^{\text {th }}$ September to $1^{\text {st }}$ October, 2011. University of Applied Sciences, Metropolitan Hotel, 385 Syngrou Ave, 17564, Athens, Greece.

Shah, M.H., (2012a). The importance of adherence to Intellectual Property Rights (IPRs) treaties/conventions for FDI inflows in emerging economies: evidence from OECD outward FDI. International Network for Economic Research, 14 ${ }^{\text {th }}$ INFER Annual Conference. 10-13 May, 2012. Faculty of Economics, University of Coimbra, Portugal.

Shah, M.H., (2012b). The significance of infrastructure for FDI inflow in developing countries. International Network for Economic Research, 14 $4^{\text {th }}$ INFER Annual Conference. 10-13 May, 2012. Faculty of Economics, University of Coimbra, Portugal.

Shah, M.H., (2012c). The effect of macroeconomic stability on inward FDI in developing countries. $7^{\text {th }}$ International Conference on Interdisciplinary Social Sciences. 25-28 June, 2012.Universidad Abat Oliba CEU, Bellesguard 30-08022, Barcelona, Spain.

Shah, M.H., (2012d). The significance of infrastructure for FDI inflow in developing countries. Challenges for Analysis of the Business and the Economy[Scientific Conference. 13-16 September, 2012. University of Applied Sciences, Bahnhofstrasse, 15745 Wildau, Berlin, Germany.

Shah, M.H., (2013a). The importance of adherence to Intellectual Property Rights (IPRs) treaties/conventions for FDI inflows in emerging economies: evidence from OECD outward FDI. European Economics and Finance Society, EEFS2013, The Twelfth Annual EEFS Conference. 20-23 June, 2013. Westin Grand, Berlin, Germany.

Shah, M.H., (2013b). The effect of macroeconomic stability on inward FDI in developing countries. European Economics and Finance Society, EEFS2013, The Twelfth Annual EEFS Conference. 20-23 June, 2013. Westin Grand, Berlin, Germany.

Shah, M.H., (2014a). The role of human capital in the host economy on inward FDI in developing countries. West East Institute, European Academic Conference Budapest, WEI 2014, $22-25$ June, 2014. Mercure Budapest Korona, Hungary. Organized by West East Institute, 19382 West Chester, PA, USA.

Shah, M.H., (2014b). The significance of infrastructure for FDI inflow in developing countries. Journal of Life Economics, (2), 1-16.

Shah, M.H., (2015). Impact of trade liberalization on FDI inflows in emerging countries. International Social Sciences and Education Research Conference ICBTS2015, 9-13 June, 2015 at Harvard University, 
Boston, Massachusetts, USA.

Shah, M.H., \& Faiz, M. (2015). Terrorism and foreign direct investment: an empirical analysis of SAARC countries. City University Research Journal. 5(2), 219-233.

Shah, M.H., \& Samdani, S. (2015). Impact of trade liberalization on FDI inflows to D-8 countries. Global Management Journal for Academic $\mathcal{E}$ Corporate Studies (GMJACS), 5(1), 30-37.

UNCTAD. (1996). World Investment Report 1996: Investment, Trade and International Policy Arrangements (Geneva: United Nations), United Nations Publication, Sales No.E.96.II.A.14.

UNCTAD. (2009). World Investment Report 2009: Transnational Corporations, Agricultural Production and Development. New York: United Nations Centre on Transnational Corporations.

Velde, D.W. (2001). Government policies towards inward foreign direct investment in developing countries: implications for human capital formation and income inequality. OECD Development Centre.

Wang, J.Y. (1990). Growth, technology transfer, and the long-run theory of international capital movements. Journal of International Economics, 29(3), 255-271. 